\title{
Use of Oat Bran in Bread: Fiber and Oil Enrichment and Technological Performance
}

\author{
Sofia Beccerica, María A. de la Torre*, Hugo D. Sanchez, Carlos A. Osella \\ Instituto de Tecnología de Alimentos, Facultad de Ingeniería Química, Universidad Nacional del Litoral, Santa Fe, Argentina. \\ Email: *marisafe@fiq.unl.edu.ar
}

Received February $21^{\text {st }}, 2011$; revised June $29^{\text {th }}, 2011$; accepted July $6^{\text {th }}, 2011$.

\begin{abstract}
The effect of different amounts of oat bran on breadmaking was studied using also additives in the formulation. The aim of this experimental work was to evaluate the technological performance of oat bran in bread and the nutritional improvement resulting from the increased content of fiber and oil. Data were analyzed by ANOVA and the results were compared by Duncan's test at a significance level of 0.05 . With the addition of oat bran, the specific volume varied in such a way that the greater the amount of bran in the mixture, the lower the specific volume of bread. The addition of the proposed additives, however, helped significantly increase the volume. Besides, a change in the fatty acid profile, with a higher content in unsaturated fatty acids, as well as larger amounts of dietary fiber, was observed.
\end{abstract}

Keywords: Bread, Dietary Fiber, Nutrition, Oat Bran, Profile of Fatty Acids

\section{Introduction}

The relationship between food and health has an increasing impact on food innovation due to the popularity of the concept of functional food. The practice of using nutrition knowledge at food product level to improve the health of the consumer leads to the general concept of functional foods. Fiber-rich foods are produced by adding functional fiber or using basic ingredients with high dietary fiber content, e.g. wholemeal bread and breakfast cereals containing whole or partially processed grain [1]. Edible, polymeric plant tissues resistant to digestion and absorption in the human small intestine but susceptible to complete or partial fermentation in the large intestine, constitute the dietary fiber. This definition includes polysaccharides, oligosaccharides, lignin and plant substances such as waxes, cutin and suberin. Cereals are important sources of dietary fiber, especially of the insoluble fraction. Total dietary fiber is divided into two fractions, one of which is soluble in water, and another which is insoluble. The latter is mainly related to intestinal regulation, including an increase in fecal bulk, reduced transit time of fecal material through the large intestine and other benefits, whereas the soluble fraction is involved in lowering the effects on blood cholesterol and glucose intestinal absorption [2]. The habitual consumption of whole grain foods is found to be associated with reduc- tion in total mortality, certain cancer mortality, ischemic stroke and type 2 diabetes [3]. Over the last two decades the acceptance of $\beta$-glucans as functional bioactive ingredients has increased the popularity and consumption of cereal-based foods as well as of many other foods fortified with cell wall-enriched grain fractions, $\beta$-glucan concentrates and isolates. In this respect, fractions rich in $\beta$-glucan have been obtained from cereal grains by dry milling, sieving, and air classification processes [4]. The mixed linkage (1-3)(1-4)- $\beta$-D-glucan ( $\beta$-glucan) of cereals possesses a number of functionalities and roles that make it unique as a plant cell wall component and as a dietary fiber [5]. These $\beta$-glucans are non-starchy polysaccharides and are found in walls of endosperm and aleurone cells of barley and oat grains [6].

Protein-lipid interactions in wheat flour dough systems are known to be important because both the lipid and the protein, primarily the gluten protein, govern the breadmaking quality of flour [7]. Although flour lipids comprise as little as $2 \%$ of flour weight, they do have a positive effect on dough formation and loaf volume in breadmaking. Polar lipids, on the one hand, have a positive effect on the loaf volume whereas non-polar lipids are detrimental [8]. The addition of exogenous food proteins to dough reduces the loaf volume of bread; however, the presence of lecithin or some detergent agents prevents such reduction [9]. 
Oat oil consists of polar and non-polar fractions, the non-polar oat lipids being comparable to other vegetable oils and having a nutritionally favourable fatty acid composition with a high content in lipid soluble antioxidant [10]. Polar lipid fraction, on the other hand, has not only a large potential to be used as emulsifier agent but promising applications also beyond food products [1113].

Hexaploid wheat (Triticum aestivum) is one of the most widely grown and important cereal crops in the world, being used for the production of numerous food and non-food products. During breadmaking, wheat flour, water, salt and yeast are mixed into a visco-elastic dough, which is subsequently fermented and baked. Wheat flour is an ideal raw material for the preparation of leavened bread mainly because of the unique properties of its protein fraction, although starch and non-starch polysaccharides also affect the quality of the final product [14]. Bread products vary widely around the world, as do their production techniques. Besides basic raw materials, other ingredients can be added to improve processing or to produce specialty and novelty breads, which often have an increased nutritional value $[15,16]$.

Beneficial metabolic and physiological effects of highfiber breads have proven to be significant at a high percentage of flour replacement, though encompassing an impairment of both dough viscoelastic characteristics and functional quality of the resulting fortified breads in terms of decreased loaf volume. This feature becomes evident from lowered gas retention, objectionable gritty texture and unsuitable taste and mouthfeel, mainly associated with a dilution of functional gluten proteins. In addition, the fiber disrupts the starch-gluten matrix and restricts gas cells to expand in a particular dimension, affecting dough viscoelastic behaviour and constraining dough machinability and gassing power [17].

On the other hand, oat has excellent moisture retention properties, keeping breads fresher for longer periods of time. Moreover, the addition of oat, oat starch, or oat lecithin to wheat bread might also retard the staling rate of the bread. Using oat in high quantities, however, may result in inferior baking quality since oat proteins, normally denatured by heat treatment, do not possess the viscoelastic properties of wheat gluten [18].

The aim of this experimental work was to evaluate the performance of oat bran in breadmaking, taking into account the improving action of its fiber and oil content.

\section{Materials and Methods}

\subsection{Materials}

Wheat flour suitable for industrial breadmaking, provided by Molinos Matilde-Santa Fe (Argentina), had the following characteristics: $11.2 \%$ protein (AACC 46-11A), $25 \%$ wet gluten (AACC 38-11), $0.65 \%$ ash (AACC 0803 ) and 14.1\% moisture (AACC Method 44-15 A) [19].

The chemical composition of the commercial oat bran used for the experience was: $17.0 \%$ protein (AACC 46-11A), 8.82\% fat (AACC 30-25), 2.10\% ash (AACC 08-03), 9.30\% moisture (AACC 44-15 A) and 27.8\% total dietary fiber (AACC 32-06) [19].

Compressed yeast, supplied by CALSA S.A.-Santa Fe (Argentina), and Optima oleomargarine $\left(36^{\circ} \mathrm{C}\right.$ melting point), by Molinos Rio de la Plata S.A., Buenos Aires (Argentina), were used as ingredients. The additive used was a mixture of ascorbic acid (one part) and BEL ASE XL11 (xilanase plus lipase) (two parts) from Guarner S.A.-Buenos Aires (Argentina).

\subsection{Fatty Acid Analysis}

The analysis of fatty acids was carried out on oleomargarine and oat bran fat by gas chromatography using a model Konik KNK-3000-HRGC gas chromatograph with a capillary column $0.25 \mathrm{~mm}$ in diameter and $60 \mathrm{~m}$ long. Working conditions were: $215^{\circ} \mathrm{C}$ oven temperature (isothermal), $240^{\circ} \mathrm{C}$ injector temperature and $250^{\circ} \mathrm{C}$ detector temperature. Oat bran fat was extracted with chloroform/methanol (2/1), this solvent being distilled in a water bath.

\subsection{Breadmaking}

The bread dough formula was as follows: 290/280/275 $\mathrm{g}$ of wheat flour, 10/20/25 g of oat bran, $15 \mathrm{~g}$ of yeast, $6 \mathrm{~g}$ of salt, $18 \mathrm{~g}$ of sucrose, $6 \mathrm{~g}$ of nonfat dry milk (NFDM), $9 \mathrm{~g}$ of fat (oleomargarine plus oat bran oil), $90 \mathrm{mg}$ of additive (30 mg ascorbic acid plus $60 \mathrm{mg}$ BEL ASE XL11) and water at a percentage corresponding to 600 brabender units (BU) in the farinograph assay for the wheat flour/oat bran mixture. The breadmaking was performed with and without the additive, ingredients being mixed for one minute in a Brabender Do-Corder Farinograph (300 g mixing bowl). The added water, with or without the additive, was warmed up to such a temperature as to obtain, at the end of kneading, a dough temperature between $24^{\circ} \mathrm{C}$ and $26^{\circ} \mathrm{C}$. After ten minutes of kneading at $60 \mathrm{rpm}$, the consistency (BU) was measured and the dough was then fermented in a fermentation chamber at $27^{\circ} \mathrm{C}$ and $80 \% \mathrm{rh}$, controlling the rising with a push meter. This apparatus consists of a glass cylinder (75 mm high, $45 \mathrm{~mm}$ i.d.) with a tight-fitting plastic piston that rises during proofing. The first fermentation ended when the dough doubled its volume (measured by a push meter displacement from 1.25 to 2.5 , approximately $40 \mathrm{~min}$ ). Then $250 \mathrm{~g}$ dough portions were laminated, rolled up, and put in molds for a second fermentation. The proofing time ended when the dough volume 
was four times the initial volume (push meter displacement from 1.5 to 6.0 , approximately $75 \mathrm{~min}$ ). Baking molds were $5.5 \mathrm{~cm}$ high, with $7 \mathrm{~cm} \times 17.5 \mathrm{~cm}$ of bottom surface and $9 \mathrm{~cm} \times 18 \mathrm{~cm}$ of top surface. Dough was baked at $210^{\circ} \mathrm{C}$ for 25 minutes in an electric oven (Ojalvo S.A., Santa Fe, Argentina).

Specific bread volume $(\mathrm{ml} / \mathrm{g})$ was determined by millet-seed displacement $60 \mathrm{~min}$ after baking. Then the loaves obtained were subjected to scoring to determine their physical characteristics on a comparative basis. Experts, in a number of three, scored the individual characteristics of the loaf which were related to those of a hypothetical standard loaf. As recommended by Pyler [20] for standard white bread and modified by Sánchez et al. [21], a typical scoring card for bread has the following point values: Volume, 15 (specific volume of $5 \mathrm{ml} / \mathrm{g}$ corresponded to the maximum value); crust, 15 (colour and thickness); crumb texture, 15 (elasticity and stickiness); crumb colour, 10 (cream white maximum score); crumb grain, 10 (alveolus size and shape, acording to Dallman) [22]; aroma, 15 (fresh breadlike); and taste, 20 (flavour and mouth feeling). Flavor was considered as the sum of aroma plus taste with a total of 35 points. Bread score was qualified as follows [23]: Excellent (90 $100)$, very good (80 - 89), good (70 - 79), acceptable (60 $69)$, poor (50 - 59), very poor (40 - 49), extremely poor $(30-39)$.

\subsection{Statistical Analysis}

Results were expressed as the mean of four replicates. Data were analyzed by ANOVA and the results were compared by Duncan's test at a significance level of 0.05 .

\section{Results and Discussion}

Table 1 shows the results corresponding to each treatment. ANOVA in Table 2 shows the significant changes produced on the responses by the addition of varying amounts of oat bran, the use of additives and the combination of both variables.

The significant differences among the average values of the responses for each percentage of oat bran with and without additive, using multiple range test, are shown in Table 3.

\subsection{Consistency at the End of Mixing}

Figure 1 corresponds to the behavior of dough consistency at the end of mixing as a function of the level of oat bran with and without the use of additive.

Minimum values of $600 \mathrm{BU}$ of dough consistency at the end of mixing were recommended by Alasino et al. [24] in order to achieve a convenient breadmaking process. It can be seen that when the additive was used, higher dough consistency values at the end of mixing

Table 1. Mean values resulting from each treatment.

\begin{tabular}{|c|c|c|c|c|c|c|}
\hline Oat bran (\%) & Use of Additive & $\begin{array}{l}\text { Consistency at the end of } \\
\text { mixing (BU) }\end{array}$ & $\begin{array}{l}\text { Specific volume } \\
(\mathrm{ml} / \mathrm{g})\end{array}$ & $\begin{array}{l}\text { Total bread score } \\
(\max .100)\end{array}$ & $\begin{array}{l}\text { Crumb texture } \\
(\max .15)\end{array}$ & $\begin{array}{c}\text { Flavor } \\
\text { (max.35) }\end{array}$ \\
\hline 0 & No & $630 \pm 20$ & $4.90 \pm 0.10$ & 90.1 & 13.5 & 31.5 \\
\hline 0 & Yes & $650 \pm 12$ & $5.50 \pm 0.15$ & 90.4 & 13.5 & 31.5 \\
\hline 10 & No & $585 \pm 17$ & $4.55 \pm 0.19$ & 88.3 & 13.5 & 31.5 \\
\hline 10 & Yes & $630 \pm 10$ & $5.25 \pm 0.17$ & 88.3 & 13.5 & 31.5 \\
\hline 20 & No & $635 \pm 12$ & $3.63 \pm 0.10$ & 76.7 & 11.3 & 29.5 \\
\hline 20 & Yes & $675 \pm 20$ & $4.73 \pm 0.10$ & 87.6 & 12.8 & 31.5 \\
\hline 30 & No & $595 \pm 12$ & $3.20 \pm 0.08$ & 71.8 & 9.0 & 28.5 \\
\hline 30 & Yes & $680 \pm 23$ & $4.33 \pm 0.15$ & 81.2 & 10.5 & 31.5 \\
\hline
\end{tabular}

Table 2. Results of analysis of variance.

\begin{tabular}{ccccc}
\hline & Consistency at the end of mixing & Specific volume & Total bread score & Crumb texture \\
Additive & $60.17^{*}$ & $336.97 *$ & $139.96^{*}$ & $24.0 *$ \\
Oat bran & $10.56^{*}$ & $187.90^{*}$ & $204.25^{*}$ & $27.0^{*}$ \\
Additive x oat bran & $4.94^{*}$ & $7.93^{*}$ & $44.25^{*}$ & $27.0 *$ \\
\hline
\end{tabular}

*significance levels at $P<0.05$. 
Table 3. Average values for the percentage of oat bran and for the use of additive Multiple Range Test.

\begin{tabular}{|c|c|c|c|c|c|}
\hline & Consistency at the end of mixing & Specific volume & Total bread score & Crumb Texture & Flavor \\
\hline \multicolumn{6}{|c|}{ Oat bran (\%) } \\
\hline 0 & $640 \mathrm{~b}$ & $5.20 \mathrm{a}$ & $90.2 \mathrm{a}$ & $13.5 \mathrm{a}$ & $31.5 \mathrm{a}$ \\
\hline 10 & 608 a & $4.90 \mathrm{~b}$ & $88.3 \mathrm{a}$ & $13.5 \mathrm{a}$ & $31.5 \mathrm{a}$ \\
\hline 20 & $655 \mathrm{~b}$ & $4.18 \mathrm{c}$ & $82.1 \mathrm{~b}$ & $12.0 \mathrm{~b}$ & $30.5 \mathrm{~b}$ \\
\hline 25 & $638 \mathrm{~b}$ & $3.76 \mathrm{~d}$ & $76.5 \mathrm{c}$ & $9.8 \mathrm{c}$ & $30.0 \mathrm{~b}$ \\
\hline \multicolumn{6}{|c|}{ Additive } \\
\hline No & $611 \mathrm{a}$ & $4.07 \mathrm{a}$ & $81.7 \mathrm{a}$ & $11.8 \mathrm{a}$ & $30.3 \mathrm{a}$ \\
\hline Yes & $659 \mathrm{~b}$ & $4.95 \mathrm{~b}$ & $86.9 \mathrm{~b}$ & $12.6 \mathrm{~b}$ & $31.5 \mathrm{~b}$ \\
\hline
\end{tabular}

Different letters mean significant differences $(P<0.05)$.

were reached, thus improving the technological behaveiour. Conversely, and according to Conti [25], the sole use of xylanases produces a softening in consistency at the end of mixing.

\subsection{Specific Volume}

Specific volume was modified by the addition of oat bran and additives. As shown in Figure 2, the greater the amount of bran in the mixture, the lower the specific volume of bread. This fact may be produced as a conesquence of the oat bran breaking down the visco-elastic structure and thereby affecting the gas retention capacity. On the contrary, the addition of the proposed additives helps dramatically increase the volume.

The effect of xilanase has already been studied by Conti [25], who states that the improvement of bread quality is due to a better gas retention in the dough, which finally results in increased bread volume. Hydrolysis of insoluble pentosans increases the viscosity of the medium and prevents the diffusion of $\mathrm{CO}_{2}$ through the mass, thereby increasing the gas retention [26,27]. Moreover, lipases produce mono and di-glycerides which

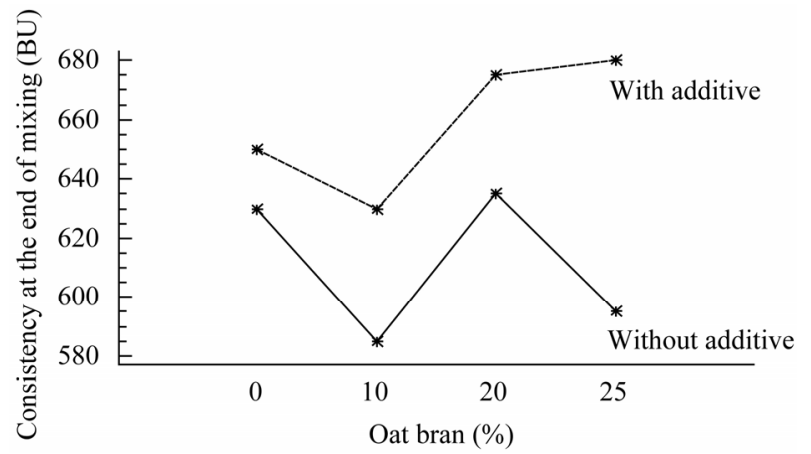

Figure 1. Consistency (BU) at the end of mixing as a function of oat bran and additive. act as emulsifiers and generate a dough structure that restricts the gas output through the dough, thus allowing an improvement in volume, dough stability and flavor [28]. Ascorbic acid, more commonly known as vitamin C, is widely used as a flour improver in bread products. The concentrations used in breadmaking are in the range between 20 and $150 \mathrm{ppm}$, depending on the wheat cultivar, the type and storage time of the flour, the breadmaking process and the type of bread. Ascorbic acid increases dough strength, reduces dough stickiness and increases tolerance to overmixing [14].

\subsection{Total Bread Score, Crumb Texture and Flavor}

Results similar to the above mentioned ones can be found when analyzing the graphs (Figures 3(a), (b), (c)), i.e. the greater the amount of bran without additives, the lower the total score, texture and flavor.

Breads rich in oat bran and produced without additives were considered acceptable by the sensory panel up to a level of $20 \%$ of oat bran, whereas up to $30 \%$ of oat bran was accepted when using also additives. However, ac-

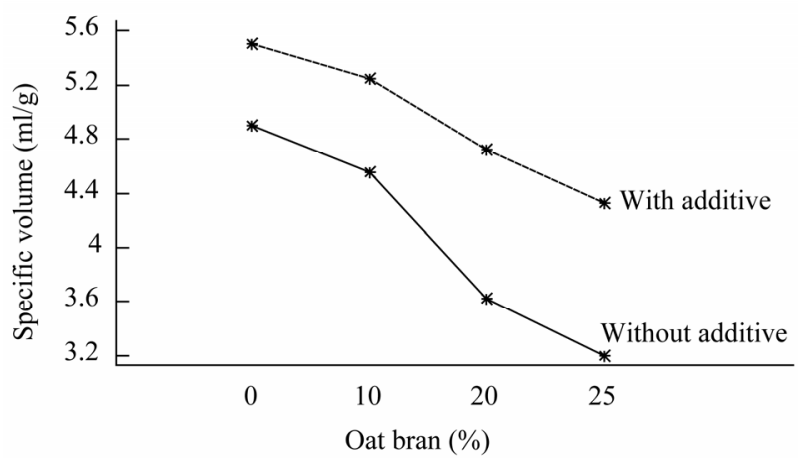

Figure 2. Specific volume $(\mathrm{ml} / \mathrm{g})$ as a function of oat bran and additive. 


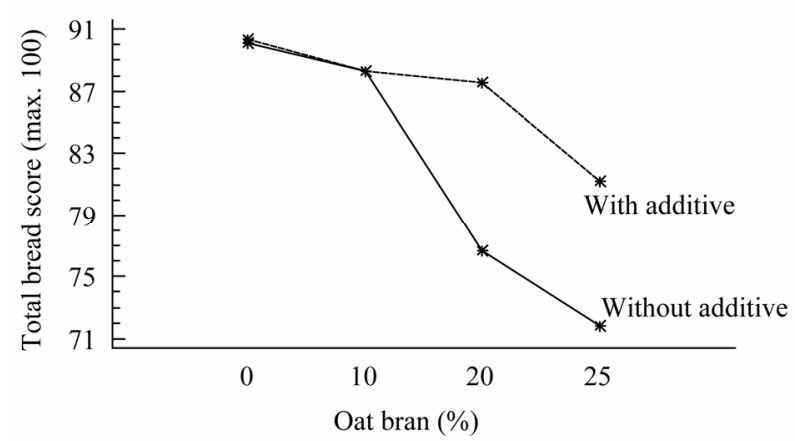

(a)

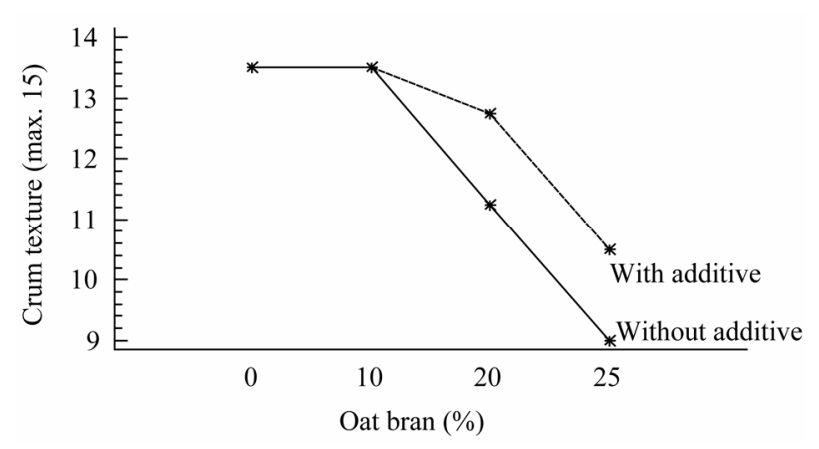

(b)

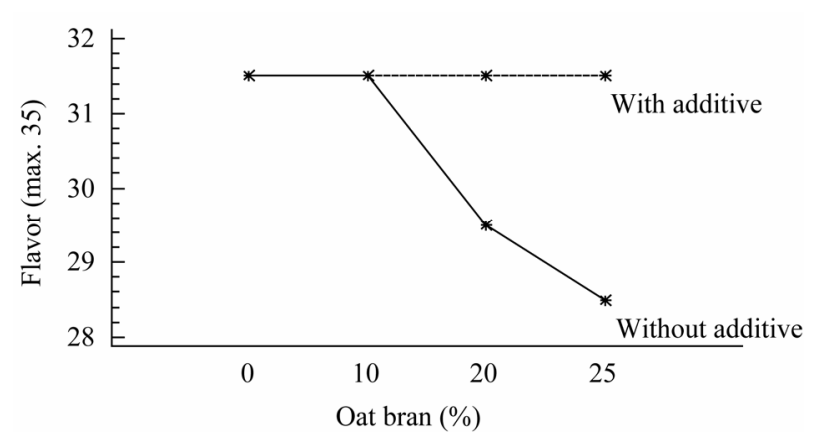

(c)

Figure 3. (a) Total bread score (max. 100); (b) Crumb texture (max. 15); (c) Flavor (max. 35) as a function of oat bran and additive.

cording to Flander et al. [18], when exceeding 20\% of oat bran, breads are more likely to show tight, moist and gummy characteristics.

\subsection{Nutrition}

Considering the high amount of unsaturated fatty acids in the oat bran oil (Table 4), it was feasible to use it to partly replace oleomargarine so as to obtain a product with a better fatty acid profile. In this work, the amount of total fat in the formulation (3\%) was kept constant, though changing the source. In this way, a fat contribution of $0.8 \%, 1.6 \%$, and $2.4 \%$ were obtained when using $10 \%, 20 \%$ and $25 \%$, respectively, of oat bran in the re- cipe.

Figure 4 clearly shows the increase in the content of poliunsaturated fatty acids because of the addition of oat bran. The content of the saturated fatty acids myristic (C14:0) and palmitic (C16:0) decreased, as well as that of oleic acid (C18:1), when the content of oat bran in the mixture was increased. On the contrary, a very signifycant increase in linoleic acid $(\omega 6) \mathrm{C} 18: 2$ and a slight increase in alpha-linolenic acid ( $\omega 3) \mathrm{C} 18: 3$ were observed when oat bran content increased.

Although oleomargarine was partly replaced by oat bran oil, the technological characteristics of the bread obtained were maintained without important modifications until $20 \%$ replacement of the wheat flour by the oat bran.

As can be seen in Figure 5, when the oat bran is added to the mixture there is a very noticeable increase in total dietary fiber (TDF) in the bread. Health benefits of dietary fiber include reduced intestinal transit time, prevention of constipation, reduced risk of colorectal cancer, decreased blood cholesterol and regulated blood glucose levels for diabetes, promoted growth of beneficial intestinal microflora (i.e., as a prebiotic, among others [29].

Table 4. Fatty acid composition of oleomargarine and oat bran oil.

\begin{tabular}{ccc}
\hline Fatty acid & Oleomargarine (\%) & Oat bran oil (\%) \\
\hline C 14 & 3.6 & 0.6 \\
C 16 & 28.8 & 18.9 \\
C 18 & 0 & 10.0 \\
C $18: 1$ & 51.6 & 40.3 \\
C 18:2 & 5.2 & 32.6 \\
C 18:3 & 1.2 & 1.9 \\
\hline
\end{tabular}

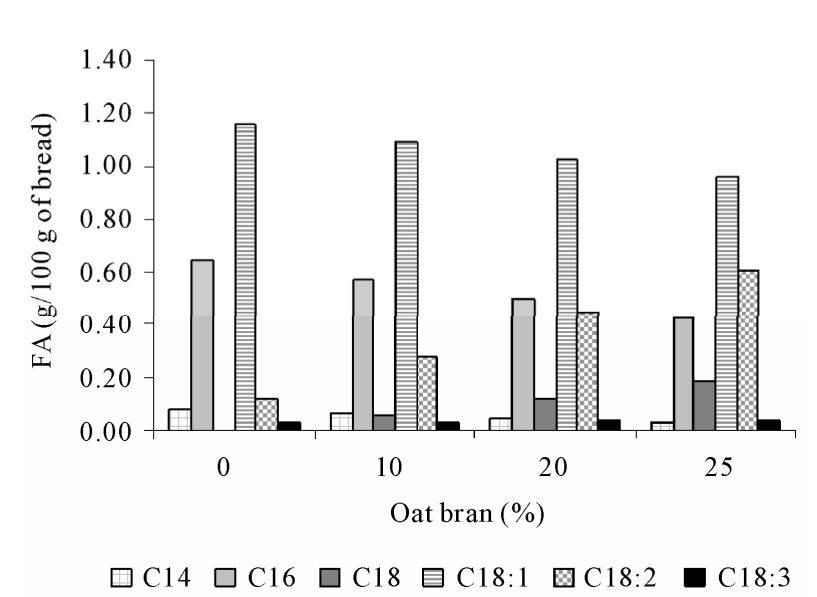

Figure 4. Composition of fatty acids of breads made with oat bran. 


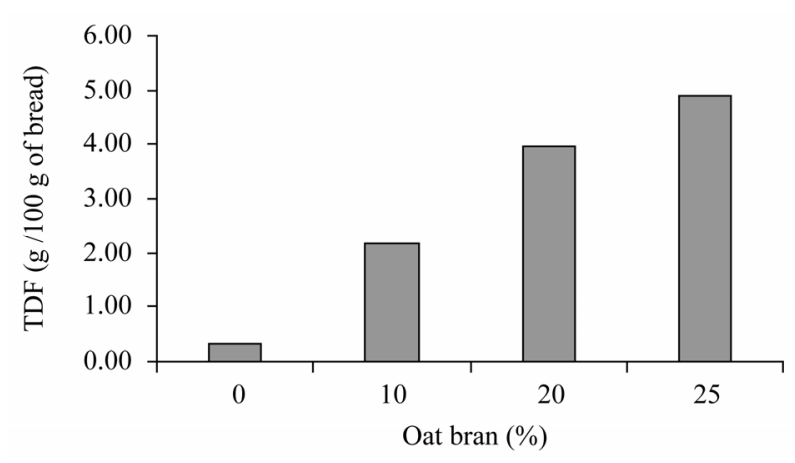

Figure 5. Total dietary fiber (TDF) in bread as a function of added oat bran.

\section{Conclusions}

The addition of oat bran to breadmaking, with the partial replacement of the formulation fat by the oat bran oil, produces a significant improvement in some nutritional aspects, namely: 1) a change in the fatty acid profile, with higher content in unsaturated fatty acids and 2) a higher content of dietary fiber with the consequent beneficial nutritional effects.

On the other hand, from the technological point of view, there is a loss of bread quality, although to a lesser extent, when the additive containing ascorbic acid, xylanase and lipase, is also used.

\section{REFERENCES}

[1] D. Peressini and A. Sensidoni, "Effect of Soluble Dietary Fiber Addition on Rheological and Breadmaking Properties of Wheat Doughs," Journal of Cereal Science, Vol. 49, No. 2, 2009, pp. 190-201. doi:10.1016/j.jcs.2008.09.007

[2] R. Carrasco-Valencia, J. Peña, H. Kallio and S. Salminen, "Dietary Fiber and Other Functional Components in Two Varieties of Crude and Extruded Kiwicha (Amaranthus caudatus)," Journal of Cereal Science, Vol. 49, No. 2, 2009, pp. 219-224. doi:10.1016/j.jcs.2008.10.003

[3] M. Deana, R. Shepherda, A. Arvolab, M. Vassalloc, M. Winkelmannd, E. Claupeind, L. Lahteenmakib, M. M. Raatsa and A. Sabac, "Consumer Perceptions of Healthy Cereal Products and Production Methods," Journal of Cereal Science, Vol. 46, No. 3, 2007, pp. 188-196. doi:10.1016/j.jcs.2007.06.007

[4] A. Lazaridou and C. G. Biliaderis, "Molecular Aspects of Cereal $\beta$-Glucan Functionality: Physical Properties, Technological Applications and Physiological Effects," Journal of Cereal Science, Vol. 46, No. 2, 2007, pp. 101-118. doi:10.1016/j.jcs.2007.05.003

[5] P. J. Wood, "Cereal $\beta$-Glucans in Diet and Health," Journal of Cereal Science, Vol. 46, No. 3, 2007, pp. 230-238. doi:10.1016/j.jcs.2007.06.012

[6] M. Papageorgioua, N. Lakhdarab, A. Lazaridouc, C. G.
Biliaderis and M. S. Izydorczyke, "Water Extractable $(1 / 3,1 / 4)-\beta$-D-Glucans from Barley and Oats: An Intervarietal Study on Their Structural Features and Rheological Behaviour," Journal of Cereal Science, Vol. 42, No. 2, 2005, pp. 213-224. doi:10.1016/i.jcs.2005.03.002

[7] I. Konopka, S. Czaplicki and D. Rotkiewicz, "Differences in Content and Composition of Free Lipids and Carotenoids in Flour of Spring and Winter Wheat Cultivated in Poland," Food Chemistry, Vol. 95, No. 2, 2006, pp. 290-300. doi:10.1016/i.foodchem.2005.01.011

[8] T. H. McCann, D. M. Small, I. L. Batey, C. W. Wrigley and L. Day, "Protein-Lipid Interactions in gluten Elucidated Using Acetic-Acid Fractionation," Food Chemistry, Vol. 115, No. 1, 2009, pp. 105-112. doi:10.1016/j.foodchem.2008.11.070

[9] T. Ukai and R. Urade, "Cooperation of Phosphatidylcholine with Endogenous Lipids of Wheat Flour for an Increase in Dough Volume," Food Chemistry, Vol. 102, No. 1, 2007, pp. 225-231. doi:10.1016/j.foodchem.2006.05.007

[10] D. M. Peterson and D. F. Wood, "Composition and Structure of High-Oil Oat," Journal of Cereal Science, Vol. 26, No. 1, 1997, pp. 121-128. doi:10.1006/jers.1996.0111

[11] D. M. Peterson, "Oat Lipids: Composition, Separation and Applications," Lipid Technology, Vol. 14, No. 3, 2002, pp. 56-59.

[12] P. M. Forssell, S. H. D. Hulleman, P. J. Myllätinen, G. K. Moates and R. Parker, "Ageing of Rubbery Thermoplastic Barley and Oats Starches," Carbohydrate Polymers, Vol. 39, No. 1, 1999, pp. 43-51. doi:10.1016/S0144-8617(98)00128-3

[13] S. V. Erazo-Castrejon, D. C. Doehlert and B. L. D'Appolonia, "Application of Oat Oil in Breadbaking," Cereal Chemistry, Vol. 78, No. 3, 2001, pp. 243-248. doi:10.1094/CCHEM.2001.78.3.243

[14] I. J. Joye, B. Lagrain and J. A. Delcour, "Use of Chemical Redox Agents and Exogenous Enzymes to Modify the Protein Network during Breadmaking-A Review," Journal of Cereal Science, Vol. 50, No. 1, 2009, pp. 11-21. doi:10.1016/i.jcs.2009.04.001

[15] K. Dewettinck, F. Van Bockstaele, B. Kuhne, D. Van de Walle, T. M. Courtens and X. Gellynck, "Nutritional Value of Bread: Influence of Processing, Food Interaction and Consumer Perception," Journal of Cereal Science, Vol. 48, No. 2, 2008, pp. 243-257. doi:10.1016/i.jcs.2008.01.003

[16] J. Wang, C. M. Rosell and C. Beneditto de Barber, "Effect of the Addition of Different Fibers on Wheat Dough Performance and Bread Quality," Food Chemistry, Vol. 79, No. 2, 2002, pp. 221-226. doi:10.1016/S0308-8146(02)00135-8

[17] J. M. Sanz Penella, C. Collar and M. Haros, "Effect of Wheat Bran and Enzyme Addition on Dough Functional Performance and Phytic Acid Levels in Bread," Journal of Cereal Science, Vol. 48, No. 3, 2008, pp. 715-721. 
doi:10.1016/i.jcs.2008.03.006

[18] L. Flander, M. Salmenkallio-Marttila, T. Suortti and K. Autio, "Optimization of Ingredients and Baking Process for Improved Wholemeal Oat Bread Quality," LWTFood Science and Technology, Vol. 40, No. 5, 2007, pp. 860-870. doi:10.1016/j.lwt.2006.05.004

[19] Approved Methods of the AACC, American Association of Cereal Chemists (AACC), Saint Paul, USA, 1994.

[20] E. J. Pyler, "Physical and Chemical Testing Methods," In: Baking Science and Technology, Siebel Publishing Company, Chicago, 1973, pp. 834-897.

[21] H. D. Sanchez, J. C. Mancuello and H. C. Fabre, "Essai de Panificaction Pour le Pain Francais," Industries de Céréales, No. 25, 1983, pp. 29-32.

[22] H. Dallmann, "Porentabelle Dallmann," In: H. Dallmann, Ed., Fortschritte der Getreideforschung, Verlag Moritz Schäfer, Detmold, 1969, pp. 2-8.

[23] E. A. Tosi, E. D. Re, R. Masciarelli, H. D. Sánchez, C. A Osella and M. A. de la Torre, "Whole and deffated Hyperproteic Amaranth Flours Tested as Wheat Flour Supplementation in Mold Breads," Lebensmittel-Wissenschaft und Technologie, Vol. 35, No. 5, 2002, pp. 472-475. doi:10.1006/fstl.2002.0892

[24] M. C. Alasino, C. A. Osella, M. A. de la Torre and H. D. Sánchez, "Use of Sodium Stearoyl Lactylate and Azodi- carbonamide in Wheat Flour Breads Added of Pea Flour," International Journal of Food Sciences and Nutrition, Vol. 62, No. 4, 2011, pp. 385-391. doi: $10.3109 / 09637486.2010 .538671$

[25] P. Conti, "Utilización de Pentosanasas (Xilanasas) en la Elaboración de Pan," Thesis Facultad de Bioquímica y Ciencias Biológicas (FBCB), Universidad Nacional del Litoral, Santa Fe, 2007.

[26] C. M. Courtin and J. A. Delcour, "Relative Activity of Endoxylanases towards Water-Extractable and WaterUnextractable Arabinoxylan," Journal of Cereal Science, Vol. 33, No. 3, 2001, pp. 301-312. doi:10.1006/jers.2000.0354

[27] M. Wang, T. Van Vliet and R. J. Hamer, "Interaction of Water Unextractable Solids and Xylanase with Gluten Protein: Effect of Wheat Cultivar," Journal of Cereal Science, Vol. 41, No. 3, 2005, pp. 251-258. doi:10.1016/j.jcs.2004.07.007

[28] L. Strayer, J. M. Berg and J. L. Tymoczko, "Bioquímica," Editorial Reverté, Barcelona, 2003.

[29] C. S. Brennan and L. J. Cleary, "The Potential Use of Cereal $(1 \rightarrow 3,1 \rightarrow 4)-\beta$-D-Glucans as Functional Food Ingredients," Journal of Cereal Science, Vol. 42, No. 1, 2005, pp. 1-13. doi:10.1016/j.jcs.2005.01.002 